\title{
Zero-Based Racial Politics: An Evaluation of Three Best-Case Arguments on Behalf of the Nonwhite Underclass
}

Richard Delgado

University of Alabama - School of Law, rdelgado@law.ua.edu

\section{Recommended Citation}

Richard Delgado, Zero-Based Racial Politics: An Evaluation of Three Best-Case Arguments on Behalf of the Nonwhite Underclass, (2012).

Available at: https://scholarship.law.ua.edu/fac_working_papers/230

This Working Paper is brought to you for free and open access by the Faculty Scholarship at Alabama Law Scholarly Commons. It has been accepted for inclusion in Working Papers by an authorized administrator of Alabama Law Scholarly Commons. 
FOR EDUCATIONAL USE ONLY

78 Geo. L.J. 1929

\author{
Georgetown Law Journal \\ August, 1990 \\ Commentary \\ *1929 ZERO-BASED RACIAL POLITICS: AN EVALUATION OF THREE BEST-CASE ARGUMENTS \\ ON BEHALF OF THE NONWHITE UNDERCLASS
}

\author{
Richard Delgado [FNa] \\ Copyright 1990 by the Georgetown Law Journal Association; Richard Delgado
}

\title{
I. INTRODUCTION
}

Both liberals and conservatives have placed issues of concern to the nonwhite poor on the back burner. Under Reaganomics, black fortunes plummeted. [FN1] For their part, the Democrats treated a black presidential candidate, Jesse Jackson, coolly, rejecting most of his platform [FN2] and snubbing him personally in the late stages of the 1988 campaign. [FN3] Every index of black and $* \mathbf{1 9 3 0}$ brown emiseration today warrants alarm. Measures of blacks' income, [FN4] net wealth, [FN5] educational attainment, [FN6] life expectancy, [FN7] infant mortality, [FN8] rates of serious illness, [FN9] drug addiction, [FN10] and incarceration [FN11] are worse than those of whites. On most of these measures, the black-white gap is increasing, [FN12] and on some, blacks stand worse off today than they did ten or even twenty years ago. [FN13]

To whom shall the nonwhite poor turn for help? The black and brown middle class is too small to carry out a rescue operation of the magnitude needed. [FN14] A coalition with some segment of white society will be necessary-but*1931 which segment? The traditional answer has been liberals, especially those of the moderate persuasion associated with the Democratic Party. Yet, if careful reflection shows that a better alliance can be made, a realignment should not be out of the question. [FN15] The continuing decline of the poor is surely a predicament no less urgent than that of a corporation whose earnings have dropped and whose shareholders are at risk of not receiving their accustomed dividends. Faced with this sort of stringency, corporations have imposed zero-based financing, requiring that longstanding operating practices be justified or cut. [FN16] Might the nonwhite poor do something similar?

I believe the time has come in the history of racial jurisprudence to ask the zero-basis question: In a society with power divided almost equally between two political groups, one conservative, one liberal, which is the more likely source of aid for the nonwhite poor? [FN17] I begin by selecting two legal and political positions that share much of the power in the United States: the moderate, principled right and the moderate, principled left. [FN18] In addition, I *1932 choose a third, the dialogic-community strand of communitarian social-welfare theory, because of its prominence in current leftist thought and the likelihood that it will become a force in social policy discussions in the years ahead. I identify and evaluate what I consider the "'best case"' arguments that can be made on behalf of the poor to each of these three groups. I identify the premises of each argument and assess its cogency and analytical power. I also address the likelihood that each argument will be effective-will move its intended audience. An argument may be analytically sound, yet there may be something about it or the group at which it is aimed that makes it unlikely to be heeded; we do not always act upon principle.

My approach leads to a three-by-two matrix: three arguments, two measures applied to each. A conventional approach, but one with a conclusion that surprised even the writer: The arguments to the right turn out to be both more convincing and more likely to be taken seriously than the ones to the left. The nonwhite poor, several million strong, should therefore 
reconsider their historic alignment with moderate liberalism and enter into a dialog with the other side. [FN19] Part II analyzes the case that can be made to the $* \mathbf{1 9 3 3}$ moderate left; Part III that to the dialogic-community variant of liberalism. Part IV analyzes the argument to the principled right.

Two premises underlie my analysis: disaggregation and competition. The former holds that we should be open to the possibility that a political group whose positions we admire on certain issues (e.g., the environment, military spending) may not be the best in other areas (e.g., support for the poor). The latter holds that nonwhites will do better if they force majoritydominated interest blocs to compete for their votes and support; alliances that are too automatic will eventually yield suboptimal results. I now turn to an examination of the arguments themselves.

\section{THE ARGUMENT TO THE MODERATE LEFT}

\section{A. THE LEFT POSITION ON SOCIAL WELFARE}

The nonwhite poor can offer a number of reasons why liberals should support social welfare services. They can argue that support is warranted because it is the morally right thing to do, because it is possible in this land of plenty to do so and there is no good reason not to, because it is helpful to the individuals concerned, because it is good for society as a whole, and because it is an integral part of combating discrimination. [FN20] These are, indeed, arguments that liberals have themselves made often and with passion.

The first argument for aiding the poor, that it is morally right, [FN21] dates back at least to the Elizabethan Poor Laws, which drew a distinction between the "worthy poor"' and paupers. [FN22] The "worthy poor"'-such as the blind, the aged, and the handicapped-were those in need through no fault of their own. They were distinguished from paupers-such as the lazy, the demoralized, and the drunk-who deserved their fate. It was society's moral obligation*1934 to make sure that members of the first group did not decline into the second. This notion that assistance is morally required struck a chord in the hearts of post-Civil War progressives [FN23] that still resonates in today's proponents of liberal social philosophy.

The moral rightness of helping the worthy poor has surfaced this century in welfare legislation grounded in New Deal principles, court decisions, and political rhetoric. Basic fairness through income redistribution was a driving impetus in the passage of legislation such as the Social Security Act, [FN24] the Fair Labor Standards Act, [FN25] and the progressive income tax. [FN26] Beginning around 1950, state courts began striking down "suitable home"' provisions in Aid to Families with Dependent Children (AFDC) [FN27] distribution schemes. Courts found these provisions, which terminated benefits if the mother was found to be engaging in extramarital sex, to unfairly punish the children (who were still "worthy"'). [FN28] These judicial decisions foreshadowed the Fleming Rulings, [FN29] which codified the rules developed in the courts. [FN30] Lyndon Johnson echoed the sentiment when he declared, ["We should wage war on poverty] because it is right that we should."' [FN31]

A second argument for affording assistance to the poor, that it is possible to do so, is related to the first and also has a lineage extending from post-Civil War progressivism to modern-day liberal dogma. In 1869, Henry George lamented that the United States was a land of "private fortunes"' side by side with "poverty and degradation."' [FN32] This same sentiment surfaced almost 100 years later in both the Economic Opportunity Act of 1964, which sought to eliminate "the paradox of poverty in the midst of plenty,"' [FN33] and statements of the AFL-CIO Executive Council such as, "[n]o nation in the history of the world has a greater capability of lifting all of its people above $* 1935$ the level of want."' [FN34] Though not relying directly on a "'moral rightness"' argument, those who frame the issue this way imply that society should aid the poor because it is irrational or wrong not to do so.

A third argument for welfare assistance, that it will help people as individuals, is grounded in the liberal principles of equality of opportunity [FN35] and equality of treatment. [FN36] The poor need assistance to overcome the effects of social isolation and limited aspirations [FN37] and "to achieve at least minimal dignity."' [FN38] Sometimes these altruistic appeals are 
buttressed by pragmatism. In 1928, George Bernard Shaw wrote that "though the rich end of town can avoid living with the poor end, it cannot avoid dying with it when the plague comes."' [FN39] President Johnson noted that "helping some will increase the prosperity of all"'; [FN40] President Kennedy said, "[i]f a free society cannot help the many who are poor, it cannot save the few who are rich."' [FN41] The Kerner Commission warned of riots and warring camps of blacks and whites if the United States did not bring poverty and racism under control. [FN42]

The final liberal argument for governmental assistance to the poor is that assistance is an integral part of protecting minority groups from discrimination. [FN43] Many liberals believe that racism and poverty are inextricably linked and must be solved together. [FN44] In this view, government assistance to the poor is a vehicle to effect social change and a necessary component of the $* \mathbf{1 9 3 6}$ liberal agenda. [FN45]

\section{B. EVALUATING THE LIBERAL ARGUMENT FOR SOCIAL ASSISTANCE}

It is not difficult to convince liberals that their position must entail welfare assistance to the poor; it is practically a defining characteristic of liberalism to be concerned with income redistribution and aid to those who suffer. [FN46] The difficulty lies in deciding what level of assistance the poor need and mobilizing support for providing it. At the core of the various liberal arguments for social welfare is the idea that helping the poor is the right thing to do. [FN47] Essentially, the arguments appeal to altruism; they speak to our finest instincts and tap sources deeply embedded in the Judeo-Christian tradition. [FN48] Yet they come without a yardstick. Once we decide to give to a deserving individual or group, how much should we give? [FN49] Liberal principles offer little, if any, guidance. Yet, it is vitally necessary to develop a measure: In times of financial stringency it is easy to balance away ill-defined rights of unpopular groups like the poor. [FN50]

The current weakening of the motivating principle liberalism relies on for support of social welfare presents an equally serious problem. This principle, altruism, [FN51] is strongest and most reliable when:

1) we fear that the same misfortune (illness, being out of work) may befall us;

2) those who suffer the misfortune confront us daily and are highly visible;

3) those who suffer strike us as being like ourselves;

4) those who suffer appear blameless with respect to their own condition;

5) our failure to give conflicts with another value we hold or our own self-concept (i.e., as a loving and generous people);

6) those in need are appealing or attractive.

*1937 All six conditions are likely to continue to weaken. Few to whom any appeal would be directed fear becoming poor or homeless themselves. Moreover, geographic separation of the rich and the poor is increasing; [FN52] few readers of this article have much daily contact with inner-city ghettos or pockets of deep rural poverty. The unfortunates we do see wandering the streets are not like us, nor are most of them particularly appealing. [FN53] Further, with the scaling down of the Cold War, we no longer find domestic poverty a liability in competition for the uncommitted Third World. [FN54] Nor do our institutions preach altruism with their previous fervor. We are more concerned with self and material well-being [FN55] and are ready to blame the poor for their own poverty; we are "conscienced out."' [FN56] Liberals are more interested in issues like the environment and military spending (which may be of low priority to the nonwhite underclass), than with subsistence welfare for the needy. [FN57] The altruistic appeal thus today provides a weak basis for asserting an obligation to provide social welfare to the nonwhite poor. [FN58]

\section{THE ARGUMENT TO THE DIALOGIC LEFT}

Over the last decade a new strain of liberalism has sprung up. Members of $* \mathbf{1 9 3 8}$ this school, represented by such authors as Alasdair MacIntyre, [FN59] Frank Michelman, [FN60] and Michael Sandel, [FN61] argue that classic liberalism's reliance on individualism and individual rights must be expanded in a more communitarian direction. Human beings can only develop their capacities through participation in social life. Affiliation is central to individuality 
and moral identity; it makes reflective life possible. [FN62] Resources, roles, and social obligations should be shared under terms to be worked out by means of a continuing dialog. [FN63] Communitarianism, essentially a blend of welfare economics, socialist political theory, and postmodern ethics, has met a generally favorable reception in legal academia. [FN64]

\section{A. THE COMMUNITARIAN POSITION ON SOCIAL WELFARE}

The best know exponent of the "dialogic community"' approach to welfare economics is Joel Handler, who urges that aid to the poor is essential to the idea of community. [FN65] Not only is supplying aid to those in need part of what the concept of "community"' means, it is also necessary instrumentally - without it the poor are excluded from social decisionmaking. If the poor are to be full members of society, they must be provided with the essential preconditions of that membership. [FN66]

*1939 Unlike the classic liberal argument, the communitarian version provides a means to determine how far the obligation to the poor extends: simply ask them. By placing the poor on boards and commissions dealing with schools, housing, Medicare, Medicaid, and other public services, we can establish a dialog that will yield the answers we seek.

\section{B. EVALUATING THE COMMUNITARIAN ARGUMENT FOR SOCIAL ASSISTANCE}

Dialogic communitarianism is an improvement on classic liberalism because it provides both an elegant argument for supporting social welfare programs and a yardstick for determining how far those programs should extend. Yet, like the classic version, it is at best a weak spur for action. The dialog between the poor (or their representatives) and the rest of society can only take place against a background of radical inequality. One group will be largely white, educated, and middle class, while the other group will be largely nonwhite and poorly educated. Social science writing on deformalized, dialogic arrangements shows that informality increases preexisting power differentials among participants and the risk that outcomes will be affected by biases. [FN67] Moreover, communitarians are only human; as many of them recognize, dialog is smoother and more enjoyable when carried on with persons like oneself. [FN68] When the participants are diverse, they must talk across a chasm of unshared experiences and cultural meanings. A lengthy $* 1940$ dialog-about-dialog may be necessary before the substantive dialog has a chance for success. But this increases the opportunities for misunderstanding, division, and cooptation. Dialog should of course be encouraged, but standing alone, the dialogiccommunitarian approach seems unlikely to provide the reliable, lasting commitment that the poor community needs.

\section{THE ARGUMENT TO THE RIGHT}

Conservative thought emphasizes self-reliance, the free marketplace, and as little governmental intervention as possible. [FN69] Accordingly, one might think that the right is an unpromising source of support for the nonwhite poor. Indeed, nonwhite populations and the poor have generally sought coalition with various strands of leftism. [FN70] Yet this reliance may be misplaced; conservative principles may be a better source of succor for the poor than has hitherto been thought, perhaps even superior to that available from the left. Certainly the current situation in which the nonwhite poor reflexively turn to an increasingly unresponsive Democratic Party leaves much to be desired. Lacking the spur of competition, moderate liberals have taken black and other nonwhite votes for granted, reduced support to these groups, and concentrated their efforts on wooing disenchanted working-class whites. [FN71]

\section{A. WHY THE PRINCIPLED RIGHT SHOULD SUPPORT SOCIAL PROGRAMS FOR THE NONWHITE POOR}

Conservatives should support social welfare programs for nonwhites because such support is implied in conservatives' own political and economic premises and it is in their self-interest to do so. [FN72] 
*1941 Conservatives believe in a free marketplace in which actors make exchanges based on self-interest. [FN73] A worker exchanges labor in return for wages; an investor or entrepreneur exchanges money or ideas in the hope of a return. Those who act imprudently will fail and be replaced by others who offer a better product or better labor, or invest more wisely.

This general approach can be tapped to yield a powerful argument for aid to the poor. A certain amount of "cultural capital"' [FN74] is an essential precondition for entry into most marketplaces. One who, from birth, lacks a minimum level of acculturation and training will be unable to make exchanges and effectively will be excluded from the marketplace. It is as though society set up a game of Monopoly, invited everyone to play, but refused to issue paper money to a few. Once a person is given the means to make exchanges, if he or she squanders it-by making a foolish investment or continually coming to work late and getting fired-we may argue that the person deserves his or her poverty and refuse to render aid. [FN75] But we cannot say this of the abject always-poor. We have never issued them the wherewithal to compete; they have never had anything to exchange. [FN76] This the conservative cannot allow, because his or her theory is based on exchanges. [FN77] Consequently, $* 1942$ conservatives must support a certain minimum level of public services for the poor.

What level? And, are we in danger of dropping below it today? The following thought experiment provides both a yardstick and an answer. Imagine an inner-city youth born to a welfare mother. [FN78] His home is a crowded, noisy tenement in a public housing project. He has never met his father. The neighborhood schools are atrocious, the teachers demoralized, discipline nonexistent, and truancy high. Vicious gangs dominate the streets outside the projects. To survive, the boy must join one of them, all of which teach a brutal ethic of crime, drugs, opposition to authority, and control of turf. By the age of sixteen, the young man has been convicted of several offenses and dropped out of school.

Imagine that this youth approaches you, the reader, a lawyer in a respected law firm or a professor at a major university. He tells you he needs a job. He offers to deliver your legal messages, clean your office after hours, or shelve books in your library. Most readers' reaction would be entirely predictable: No. The youth lacks the cultural capital to work for you or anyone else. He is unlikely to know basic things he needs to function in your world. He is alien, he is "Other."' You would fear him; you would prefer to hire someone with a greater foothold in your world. I would do the same.

Principled conservatives cannot allow youths like the one in the example to exist. Yet they do, in large numbers, [FN79] their education, nutrition, medical care, and nurturing falling below the minimum necessary to enable them to enter into exchanges with people like you and me. They effectively are rendered economic nonpersons, unable to enter legitimate marketplaces, hold jobs, make investments, and purchase property. The conservative is not only logically bound to remedy this problem, he or she should be strongly motivated*1943 to do so. Youths like the one in the thought experiment would be entitled to revolt, violently if necessary, against society. [FN80] Our system has little, if any, claim to their loyalty. Arguably, they would be justified in taking by force the essential life commodities that society has failed to provide them. [FN81] Conservatives have a greater stake than others in seeing that this does not happen. Often wealthier than their liberal counterparts, [FN82] they have the most to lose from the crime and disruption that results from unmet human needs. [FN83] More attuned to business values, conservatives may react sympathetically to job training that will help meet the threat of foreign competition, while at the same time reducing crime and disruption. [FN84]

\section{B. ANALOGOUS SUPPORT FOR THE CONSERVATIVE ARGUMENT: THE CASE OF BANKRUPTCY}

One area where similar arguments have been put forward is bankruptcy. [FN85] The institution of bankruptcy, favored by conservatives and liberals alike, is said to serve two principal purposes. [FN86] First, it permits individuals to avoid the discouragement and suppression of productivity that can result from an unpayable amount of debt. [FN87] The second purpose is humanitarian: Experience teaches that the free market produces persons who find themselves saddled*1944 with overwhelming debt through no fault of their own. [FN88] These victims of our rough-and-ready system deserve a second chance. Next time their fortunes may improve; we are not yet ready to write them off. [FN89] 
Both arguments apply at least as strongly to the ghetto youth of my imaginary example. A businessperson whose venture fails gets a "fresh start."' The youth, by contrast, needs a start; unlike the entrepreneur, he never had one. Unless the youth has an opportunity to enter into exchanges, society will never benefit from whatever labor, inventions, and enterprise he may have produced. [FN90] Moreover, the youth, deprived of any meaningful opportunity to rise, can scarcely be blamed for his condition. Both the social-utility and humanitarian reasons for bankruptcy apply with equal or greater force to individuals whose chances in life are near zero, who have been "bankrupt since birth."DD'

\section{EVALUATING THE ARGUMENT TO THE RIGHT}

Possible weaknesses in the argument to the right include: (1) that conservatives care mainly about business values and welfare spending is inimical to the business climate; and (2) that the right hate the poor and are unlikely to wish to have much to do with them.

It is true that subsistence programs for the poor will raise taxes and so may have a shortterm negative impact on the economy. But a much greater threat to the economy is posed by foreign competition-by the rapidly expanding economies of Japan, Korea, and other emerging countries. A principal reason why these countries threaten our markets is that they have highly motivated and educated workforces. American business leaders recognize that to compete, the pool of United States workers able to handle demanding, technical work must be increased. As minorities become an even larger proportion of the United States population, educational and job training programs for members of these groups will be increasingly essential to a healthy economy. [FN91]

*1945 It may also be true that some on the political right hold a visceral dislike for the poor: their perceived sexuality, high reproductive rate, music, and disinclination to work. Yet at least some conservatives are eager to help nonwhites who are struggling to rise. Witness the recent instances in which wealthy industrialists and churches have promised to sponsor the education of inner-city children who agree to stay out of trouble. [FN92] Further, the right and the nonwhite poor are arguably natural allies on certain issues, such as the environment and military spending. [FN93] Both oppose drugs and favor strong families and religion. These convergences could be marshaled in favor of a coalition, particularly if the right recognized that it could enable them to win several million votes and administer a final, stinging defeat for the left. Finally, because those on the right are often more deeply religious than those on the left, appeals based on basic human dignity and Judeo-Christian values may move them more than they move others.

\section{THE CULTURAL CAPITAL ARGUMENT: SUPREME COURT CASE LAW AND THE PSYCHOLOGY OF LEGAL CLAIMING}

On a number of occasions, the Supreme Court has considered whether the Constitution contains a duty for the federal or state governments to provide their citizens with certain necessities of life. Each time the Court has held that it does not. Many of the cases were decided during the heyday of judicial activism, yet each opinion was by a clear or large majority. [FN94]

In Lindsey v. Normet, [FN95] the Court considered a claim that housing is such a basic necessity that it must be treated as a "fundamental interest"' that may only be subordinated when a state is able to show some superior, "'compelling"*1946 interest. [FN96] The Court rejected this claim, stating that "the Constitution does not provide judicial remedies for every social and economic ill."' [FN97] In San Antonio Independent School District v. Rodriguez, [FN98] the Court quoted Lindsey in denying a claim that markedly unequal school finance schemes violated the fourteenth amendment's equal protection clause. [FN99] The Court held that although education may be essential to earning a living and exercising one's rights as a citizen, [FN100] nothing in the Constitution requires that every child be afforded perfectly equal schooling. [FN101]

In Dandridge v. Williams [FN102] the Court most unequivocally rejected the idea that welfare is a constitutional right. In Dandridge, several welfare recipients with large families challenged a Maryland rule that provided a decreasing schedule of AFDC payments for each 
person after the initial beneficiary and a fixed increment per person for families larger than ten. [FN103] The welfare recipients challenged the maximum grant provisions as a violation of equal protection. A district court agreed with them, but the Supreme Court reversed, holding that Maryland's fee schedule, although it discriminated against large families, fell within the scope of permissible social/economic legislation and had to be sustained if it had any reasonable basis. [FN104]

Reading these decisions together, it appears the Supreme Court will give the political process a free hand in determining the distribution of welfare benefits even when "the most basic economic needs of impoverished human beings"' are concerned. [FN105] Neither the liberal nor the conservative, the generous nor the stinting, the communitarian nor the laissezfaire position on welfare needs is constitutionally mandated. Within broad limits, society is free to adopt any basis for, and provide, benefits to any extent that it wishes. [FN106]

*1947 One's first impulse may be to decry this result. But I believe that judicial rejection of subsistence rights focuses attention on potentially sounder bases for improving the lot of the poor. [FN107] Throughout history, reform litigation has proven a disappointment for the disempowered-slow, frustrating, and costly in energy better spent elsewhere. Going to court to pursue a new civil right, or even to enforce an old one, requires that the victim emphasize, even exaggerate, his or her victimhood in a socially prescribed, ritualized way that many find inconsistent with human dignity and self-regard. [FN108] Even when civil rights claims are successful, the newly established rights are often quickly and quietly cut back by narrow judicial interpretation, foot-dragging, and delay. [FN109] Litigation is not a useless strategy, but it rarely offers solid gains and is apt to induce the supplicant syndrome. As I have argued, better avenues are available to the nonwhite poor: power, coalition-building, and politics.

\section{CONCLUSION}

The nonwhite poor's predicament is acute and worsening. Because Supreme Court cases indicate the poor can expect little help from the courts, their best avenue for relief will be the political arena, where their increasing numbers offer at least the cold comfort that majority-race groups will need to take them seriously. I believe my evaluation of three "best case"' arguments has shown that the nonwhite poor's most logical ally is the principled right. The argument to the right has not been fully articulated, yet it is both more cogent and more likely to be heeded than those to the two major liberal positions.

To gain the attention of any majoritarian political group, the poor will need to be strident, demanding, and willing to engage in disruption if need be-in a word, radical. [FN110] Yet once mobilized, their best friends, in a paradox*1948 worthy of our times, may be members of the principled right rather than their now tepid traditional allies, the moderate left. [FN111] [FNa] Charles Inglis Thomson Professor of Law, University of Colorado Law School. J.D., U.C.Berkeley, 1974. I am grateful to Guy DuBeau, Charles Church, and Lisa Delgado for research assistance, and to Michael Olivas, Steve Shriffin, and the University of Maryland School of Law Legal Theory Workshop for helpful criticism and encouragement.

[FN1]. See generally THE REAGAN EXPERIMENT (J. Palmer \& I. Sawhill eds.1982) (collection of essays on changes in economic and social policies in the early years of the Reagan Administration). See Cockburn, All in Their Family, THE NATION, July 24/31, 1989, at 113, 114 (citing statistics); Poor Measures-A Study Chronicles Poverty's Rise, TIME, Mar. 5, 1984, at 14; see also Delgado, Derrick Bell and the Ideology of Racial Reform: Will We Ever Be Saved?, 97 YALE L.J. 923 (1988) [hereinafter Delgado, Ever Saved?] (on the recent decline and its connection with ideology).

I have chosen to focus on the nonwhite poor because theirs is the most acute and intractable form of poverty. Most American blacks and Hispanics are not poor, and at any moment poor whites outnumber poor black and brown people. But white poverty generally does not persist from one generation to the next-white people move in and out of poverty in a way that nonwhite poor do not. See W.J. WILSON, THE TRULY DISADVANTAGED 174-77 (1987); Karst, Citizenship, Race, and Marginality, 30 WM. \& MARY L.REV. 1, 4 (1988); cf. U.S. BUREAU OF THE CENSUS, STATISTICAL ABSTRACT OF THE UNITED STATES, 1989, 452 (table 734) 
(1989) [hereinafter STATISTICAL ABSTRACT] (listing number of persons below poverty level and below 125 percent of poverty level from 1959 to 1987, with breakdown by race). For the view that blacks have made steady progress (at least until lately) since Gunnar Myrdal published his masterwork on race relations, G. MYRDAL, AN AMERICAN DILEMMA (1944), see Smith \& Welch, Black Economic Progress After Myrdal, 27 J.ECON.LIT. 519 (1989). For the contrary view, see Delgado, Ever Saved?, supra.

[FN2]. See Excerpts from the Democratic Platform: "A Revival of Hope,"' N.Y. Times, Jul. 20, 1988, at A20, col. 1 (including minority planks not adopted). Jackson's social platform, especially that dealing with the problems of blacks and the poor, was the least receptively treated.

[FN3]. See Oreskes, Aides to Jackson Say Dukakis Seeks Curb on His Role, N.Y. Times, Sept. 1, 1988, at A1, col. 6 [hereinafter Oreskes, Aides to Jackson]; Oreskes, Jackson Concedes Fight Over Bentsen is Possible, N.Y. Times, July 14, 1988, at A20, col. 1; see also Curry, A Season in Hell, MS. MAGAZINE, Oct. 1989, at 59, 62; Wicker, Bush and the Blacks, N.Y. Times, Apr. 16, 1990, at A13, col. 3 ("black approval of Mr. Bush was based partly on black resentment of a Democratic Party that they think takes them for granted."'); McGrory, GOP Just Won't Let Dems Forget Jackson, Newsday, Feb. 15, 1989, at 60, col. 1; Sloyan, GOP Woos Blacks-and Jackson, Newsday, Aug. 16, 1988, at 21, col. 1; Dionne, Dukakis and Jackson Agree to Unite for Fall Campaign As Party Opens Convention: Talks Yield Accord, N.Y. Times, July 19, 1988, at A1, col. 6.

[FN4]. See STATISTICAL ABSTRACT, supra note 1, at 422 (table 721); Hacker, American Apartheid, N.Y.REV. BOOKS, Dec. 3, 1987, at 26, col. 1; Handler, The Transformation of Aid to Families with Dependent Children: The Family Support Act in Historical Context, 16 N.Y.U.REV.L. \& SOC. CHANGE 457, 512 (1987-88) [[[hereinafter Handler, Transformation]; see also Coontz, "The Family"' Has Many Definitions, The Christian Science Monitor, Feb. 27, 1989, at Opinion 18 (real annual income of young black men dropped 50\% since 1974); McLeod, Report Says Poverty Increasing for Hispanics Living in U.S., San Francisco Chron., Nov. 4, 1988, at A4, col. 4.

[FN5]. See STATISTICAL ABSTRACT, supra note 1, at 459 (table 746).

[FN6]. See id. at 130-31 (tables 211-12); SAT Race, Gender Gap Widening, Wis.St.J., Sept. 12, 1989, at 2A, col. 5; Cockburn, supra note 1, at 114 .

[FN7]. See STATISTICAL ABSTRACT, supra note 1, at 70; 2 U.S. DEP'T OF HEALTH \& HUMAN SERVICES, VITAL STATISTICS OF THE UNITED STATES, pt. A, § 6, at 11 (table 6-3) (1988) [hereinafter VITAL STATISTICS]; Gresham \& Wilkerson, The Burden of History, THE NATION, July 24/31, 1989, at 115 (black life span declined two years in a row, while that of whites rose).

[FN8]. See STATISTICAL ABSTRACT, supra note 1, at 77 (table 115); VITAL STATISTICS, supra note $7, \S 1$, at 4 (table $1-3$ ).

[FN9]. See Blacks Blame Bad Health on Low Self-Image, San Francisco Chron., July 7, 1989, at 9, col. 3 (reporting national meeting of black physicians).

[FN10]. See Kerr, Addiction's Hidden Toll: Poor Families in Turmoil, N.Y. Times, June 23, 1988, at A1, col. 1, B4, col. 3; Shapiro, The Ghetto: From Bad to Worse, TIME, Aug. 24, 1987, at 18.

[FN11]. See U.S. DEP'T OF JUSTICE, FED. BUREAU OF PRISONS, STATISTICAL REPORT FISCAL YEAR 1986, at 104 (table C-5) (1986); Cockburn, supra note 1, at 114 (today more black men are in jail than in college).

[FN12]. See W. BUTZ, MONEY, INCOME \& POWER BY STATES IN THE UNITED STATES: 1987 
(Advance Report No. 161, Current Population Rep. 60 (1988)); see also Gloomy Report for Blacks, San Francisco Chron., Aug. 8, 1989, at A9, col. 5 (National Urban League Report); Expert on U.S. Poverty Says It Got Worse in the 1980s, id., July 5, 1989, at B8, col. 4 (Census Bureau expert Mark Littman finds that the "poverty gap"' has not decreased in the 1980's). For a review of several studies of the urban poor, see Raymond, Scholars Examining the Plight of the Urban Poor Broaden Scope of Research on the 'Underclass', Chron. Higher Ed., Nov. 29, 1989, at A4, col. 2.

[FN13]. See Cockburn, supra note 1, at 114 (not one black CEO in top 1000 U.S. corporations); see also Hacker, supra note 4; Still Separate and Unequal, TIME, June 19, 1989, at 37 (35 years after Brown, much school segregation remains); Coughlin, Report Blames Racism and a Sagging U.S. Economy for Stagnation in Progress of Black Americans, Chron. Higher Ed., Aug. 2, 1989, at A4 (National Academy of Sciences Report); Hays, Prejudice in Suburbs is Aimed Mostly at Blacks, N.Y. Times, Nov. 23, 1988, at A16, col. 1 ("[s]trong penalties for being black,"' reflected in pattern of housing segregation in U.S. cities).

[FN14]. See Fellis, The Black Middle Class, After Years of Hard-Won Progress, Signs of Stagnation are Appearing, BUS. WEEK, Mar. 14, 1988, at 62; Bernstein, 20 Years After the Kerner Report: Three Societies, All Separate, N.Y. Times, Feb. 29, 1988, at B8, col. 1.

[FN15]. Black leaders have been dropping veiled and not-so-veiled hints of this lately. See Waters, Government Must Respond: Drugs, Democrats, and Priorities, THE NATION, July 24/31, 1989 , at 141, 143 ("I have supported the Democratic Party all my life."' But "[with] respect to Democratic Party politics, black voters should constantly seek vehicles through which they can make statements and pursue change."'); McGrory, supra note 3; Oreskes, Jackson, 'Too Mature to be Angry,' Icily Offers No Embrace for Ticket, N.Y. Times, July 13, 1988, at 1, col. 4 (after 1988 convention rejected most of his platform and put distance between Democrats and blacks, Jesse Jackson reminds Democrats that there is, after all, another political party); see also Lewis, This Bush Thing Isn't As Bad As Was Expected, Wis.St.J., Sept. 15, 1989, at 17A, col. 1 ("confession"' by black columnist Claude Lewis that although he has "not gone all the way over to Bush . . . at least now, he is an open question"'). The GOP has reciprocated with some cautious overtures of its own; see, e.g., McGrory, supra note 3; Raspberry, Jack Kemp Challenges the Bureaucracy to Help the Poor Buy Homes, Denver Post, May 16, 1990, at 7-B, col. 1 (Secretary of Housing and Urban Development pledges to shift public housing towards tenant management); Sloyan, supra note 3 (overtures by President Bush and Pierre DuPont).

\section{[FN16]. See generally P. PYHRR, ZERO-BASE BUDGETING (1973).}

[FN17]. The answer, I realize, may well be different for middle-class blacks and Hispanics. I am less concerned about them. They may face daunting obstacles of their own (see immediately infra, this note), but they also possess greater resources. Accordingly, I exempt them from my inquiry.

Middle- and professional-class people of color find that prejudice is no less virulent as one moves up the occupational ladder. See Clark, Contemporary Sophisticated Racism, in THE DECLINING SIGNIFICANCE OF RACE: A DIALOG AMONG BLACK AND WHITE SOCIAL SCIENTISTS 105 (J. Washington ed.1978); Cockburn, supra note 1, at 114; Delgado, Words That Wound: A Tort Action for Racial Insults, Epithets, and Name-Calling, 17 HARV.C.R.C.L.L.REV. 133, 138 (1982) and sources cited therein; Gold, Black Professionals Battle Isolation, N.Y. Times, May 5, 1989, at Y7, col. 2; see also Lacayo, Between Two Worlds, TIME, Mar. 13, 1989, at 58 (blacks in middle class).

[FN18]. The term "liberal,"' like the term "conservative,"' is of course a social construct. Both represent polar positions that most of us fall in between (or further out on the spectrum), taking different positions on different issues. The differences between left and right are often only a matter of degree. What is considered liberal in one era may be regarded as conservative in another, and vice versa. 
Today, liberals are increasingly attuned to marketplace considerations; as the economy becomes more endangered by foreign competition, politics (even liberal politics) is "turning right."' Nonetheless, differences between the two groups remain. Conservatives generally believe in a purer form of marketplace economics than do leftists. They are against regulation, and oppose most welfare programs and taxation for anything other than the most basic reasons (defense, bridges, roads). For examples of writing in the principled-right mold, see the works of Milton Friedman, George Gilder, Glen Loury, Thomas Sowell, and the Chicago school of economics generally. See also C. MURRAY, LOSING GROUND (1984) (criticizing social welfare politics on pragmatic and moral grounds).

[FN19]. See supra note 15; Delgado, Legal Storytelling for Oppositionists and Others: A Plea for Narrative, 87 MICH.L.REV. 2411, 2435-41 (1989). I am not suggesting that this observation holds true for culture-lovers, war resisters, middle-class blacks, or others. Those groups are probably already correctly aligned (monied, high-culture lovers with the moderate right, peace lovers and middle-class minorities with the moderate left). It is only the nonwhite poor who I suggest should consider changing their alignment.

In fact, convergences of the interests of the conservatives and the poor community have been occurring in increasing numbers lately. Many inner-city dwellers were among the loudest in praise of President Bush's announced war on drugs, and U.S. Hispanics joined with conservatives and business organizations in opposing employer sanctions in the new immigration bill. See Brownstein, Inner Cities, Outer Politics and Underclasses, Politics by Drawbridge, L.A. Times, Oct. 8, 1989, § 5, at 1 (inner city support for tough measures against drug problem); Applebome, Democrats Vying for Hispanic Votes, N.Y. Times, June 29, 1987, at B7, col. 1 (reporting Hispanic concerns over employer sanctions in new immigration bill); Shapiro, Aliens Bill Sanctions Approved, Wash. Post, June 14, 1984, at A1 (Hispanic groups joined with business groups to oppose sanctions on employers hiring illegal aliens fearing discrimination against legitimate workers); see also Raspberry, supra note 15 (discussing efforts of Jack Kemp to foster tenant management of low income public housing); Kamarck, Frustrated by Bureaucracy, Poor People Seek Allies on the Right, Denver Post, May 7, 1990, at B7, col. 1 (discussing recent alignments between conservatives and the poor on the issues of education and housing).

Germany under Bismarck (an extreme conservative) saw a flourishing of welfare reform measures. See A. WHITE, SEVEN GREAT STATES 501 (1915) (discussing Bismarck's compulsory state insurance for workers). Recently Mario Vargas Llosa, the award-winning novelist of impeccable reformist credentials and a presidential candidate in Peru, has suggested that resolution of his country's poverty problems may entail rapprochement with the right. See Garcia, Politics is Now His Muse, TIME, Apr. 9, 1990, at 56; Riding, Lima Journal, N.Y. Times, Aug. 29, 1988, at A4, col. 3; Castaneda, Vargas Llosa Gives Peru A Dangerous Plot For Democracy, L.A. Times, Sept. 28, 1987, at pt. 2, p. 7, col. 1. For early discussions of left/right alliances, see W.E.B. DuBois, The Republicans and the Black Voter, THE NATION, June 5, 1920, at 757 ; id., Oct. 17,1928 , at 392.

[FN20]. For examples of writings on welfare rights by the liberal mainstream, see the work of Daniel Moynihan, William Julius Wilson, Roger W. Wilkins, and authors and works cited infra notes 21-43.

[FN21]. See Message to the Congress of the United States from President Lyndon Johnson, 110 Cong.Rec. 5287 (1964) [hereinafter Message to Congress] (announcement of the "War on Poverty"'); see also Edelman, State Action Created the Poverty Trap, and Should Spring It, Legal Times, Mar. 6, 1989, at 20 (failure of the War on Poverty means the poor need a fundamental right to a minimum standard of living). There are, of course, almost infinite varieties of liberal. See Shiffrin, Liberalism, Radicalism, and Legal Scholarship, 30 UCLA L.REV. $1103,1106-20$ (1983). With respect to welfare rights, however, it is possible to generalize; most liberals embrace one or more of the views discussed in this Part.

[FN22]. See J. HANDLER, REFORMING THE POOR; WELFARE POLICY, FEDERALISM, AND 
MORALITY 7-10 (1972). On the rise of the welfare state, see Kudrle \& Marmor, The Development of Welfare States in North America in THE DEVELOPMENT OF WELFARE STATES IN EUROPE AND AMERICA 81 (P. Flora \& A. Heidenheimer eds.1981).

[FN23]. See Ferman, Editor's Preface, in POVERTY IN AMERICA xvi (L. Ferman, J. Kornbluh \& A. Haber eds.1965). On the development of welfare thought during the Progressive era, see G. KOLKO, THE TRIUMPH OF CONSERVATISM (1963).

[FN24]. Ch. 531, 49 Stat. 620 (1935) (codified as amended at 42 U.S.C. §§ 301-1397f (1982)).

[FN25]. Ch. 676, 52 Stat. 1060 (1938) (codified as amended at 29 U.S.C. § § 201-219) (1988).

[FN26]. See A. LAFRANCE, WELFARE LAWS: STRUCTURE AND ENTITLEMENT IN A NUTSHELL 291 (1979); see also D. HAMILTON, A PRIMER ON THE ECONOMICS OF POVERTY xii-xiii (1968) (social revolution of the 1930 s made viable by later growth in the productive capacity of the economy and a more egalitarian sharing of wealth).

[FN27]. 42 U.S.C. §§ 601-615 (1982).

[FN28]. See A. LAFRANCE, supra note 26, at 292.

[FN29]. 42 U.S.C. § 604 (1962).

[FN30]. See A. LAFRANCE, supra note 26, at 292.

[FN31]. See Message to Congress, supra note 21, at 5287.

[FN32]. H. GEORGE, PROGRESS AND POVERTY (1905) (discussing the distribution of property in a progressive society).

[FN33]. D. HAMILTON, supra note 26, at 101 (discussing the "War on Poverty"').

[FN34]. A.F.L.-C.I.O. Executive Council Statement, Waging War on Poverty, in POVERTY IN AMERICA, supra note 23 , at 428.

[FN35]. See D. Hamilton, supra note 26, at 118-19 (discussing ways to increase opportunities for the poor).

[FN36]. See Karst, supra note 1, at 3; Lawson, Individuals and Groups in the American Democracy, in POVERTY, JUSTICE, AND THE LAW: NEW ESSAYS ON NEEDS, RIGHTS AND OBLIGATIONS 105 (G. Lucas, Jr. ed.1986).

[FN37]. See generally W.J. WILSON, supra note 1 (discussing the social pathologies of the inner city); Keyserling, Planning a Long-Range Balanced Effort, in POVERTY IN AMERICA, supra note 23 , at 434.

[FN38]. A. LAFRANCE, supra note 26, at 83 (noting use of this argument to support direct transfer programs such as the Social Security Act).

[FN39]. Shaw, The Intelligent Woman's Guide to Socialism and Capitalism, in POVERTY IN AMERICA, supra note 23 , at vi.

[FN40]. See Message to Congress, supra note 21, at 5287. Writers have recognized the potential loss of resources such as "the Nobel Prize winners [[[who waste] away in Harlem tenements."' D. HAMILTON, supra note 26, at 19. 
[FN41]. P. WONNACOTT \& R. WONNACOTT, ECONOMICS 752 (3d ed.1986) (quoting President Kennedy).

[FN42]. See REPORT OF THE NATIONAL ADVISORY COMMISSION ON CIVIL DISORDERS (1968) [hereinafter Kerner Commission Report] (examining racial disorder in America following unrest of 1960s).

[FN43]. See ]. GREENSTONE \& P. PETERSON, RACE AND AUTHORITY IN URBAN POLITICS 71 (1973) (discussing class and racial interests in the struggle over community participation).

[FN44]. See id.; W.J. WILSON, THE DECLINING SIGNIFICANCE OF RACE 141-43 (1980) (tracing the development of a black class structure and relating it to the declining influence of race in the economy).

[FN45]. See West, Race and Social Theory: Toward a Genealogical Materialist Analysis, 2 THE YEAR LEFT 74, 77-79 (1989) (many liberals mistakenly hold that problems of race are essentially ones of class and that discrimination will end when African-Americans have more money).

[FN46]. See supra notes 21-37 and accompanying text.

[FN47]. See id.; Ferman, supra note 23, at xvii-xx.

[FN48]. The Bible exhorts its readers to consider, and have mercy on, the poor. See, e.g., Psalms 41:1; Proverbs 19:1, 17; Matthew 19:21.

[FN49]. See J. RAWLS, A THEORY OF JUSTICE 157, 285 (1971) (citing this difficulty in support of his "difference principle"').

[FN50]. See Piven \& Cloward, The Contemporary Relief Debate, in THE MEAN SEASON: THE ATTACK ON THE WELFARE STATE 45 (1987). Cf. infra Part IV.

[FN51]. On altruism, see the various articles in ALTRUISM, MORALITY, AND ECONOMIC THEORY (E. Phelps ed.1975). On the current crisis in democratic theory precipitated by economic decline and the increasing demand for welfare assistance, see Przeworski \& Wallerstein, Democratic Capitalism at the Crossroads, in CAPITALISM AND SOCIAL DEMOCRACY 205 (A. Przeworski ed.1985).

[FN52]. See, e.g., W.J. WILSON, supra note 1, 33-46 (geographical relocation of jobs away from inner city); "Hypersegregation"': Study Finds More Isolation of Blacks, San Francisco Chron., Aug. 5, 1989, at A2, col. 3 (status of blacks has regressed in comparison to whites since the 1970 s and blacks are unlikely to share a neighborhood "with any whites at all"').

[FN53]. See Homeless in America: Hard Times, NEWSWEEK, Mar. 21, 1988, at 46 (photographic essay).

[FN54]. On the role of international politics in shaping domestic reform movements, see Dudziak, Desegregation as a Cold War Imperative, 41 STAN.L.REV. 61 (1988). Poverty is a liability in our competition with Korea and Japan and is a matter of great potential concern to business leaders. See supra note 18; infra note 77.

[FN55]. On the rise of materialism and concern for self, see generally R. BELLAH, HABITS OF THE HEART (1985); J. GALBRAITH, THE AFFLUENT SOCIETY (1958).

[FN56]. See Cockburn, supra note 1, at 113-14; Gresham, The Politics of Family in America, THE NATION, July 24/31, 1989, at 116,120; Karst, supra note 1, at 3; Epstein, The Joys of 
Victimhood, N.Y. Times Mag., July 2, 1989, at 20; see also B. EHRENREICH, FEAR OF FALLING: THE INNER LIFE OF THE MIDDLE CLASS 9 (1989) (affluent families worrying about own position, less concerned about social problems of poor and others).

[FN57]. Environmentalism appeals mainly to those who already have jobs. Like cuts in military spending, environmental programs generally leave the poor (as well as Republicans) cold.

[FN58]. One can argue that the left lacks power and control, but not will, and that if liberals were in power, things would change. But this "trust us"' view is unconvincing. The moderate left's pursuit of working-class whites to the exclusion of blacks, see infra note 71 and accompanying text, has been too dominant of late to allow much hope of such a transformation. Moreover, the ostensibly liberal Democrats control not only Congress, but also many state and local governments, where their support of nonwhite groups has not been much better (outside a few all-black cities). See Crenshaw, Race, Reform, and Retrenchment, 101 HARV.L.REV. 1331, 1362 n. 119, 1376 \& n. 174 (1988) (Democrats believe recent downturn in party's fortunes caused by over-identification with minorities).

[FN59]. See A. MACINTYRE, AFTER VIRTUE (2d ed.1984).

[FN60]. See Michelman, The Supreme Court, 1985 Term-Foreword: Traces of SelfGovernment, 100 HARV.L.REV. 4 (1985).

[FN61]. See M. SANDEL, LIBERALISM AND THE LIMITS OF JUSTICE (1982).

[FN62]. See id. at 5-7; Simon, Rights and Redistribution in the Welfare System, 38 STAN.L.REV. 1431, 1437 (1986); Taylor, The Nature and Scope of Distributive Justice, in PHILOSOPHY AND THE HUMAN SCIENCES 292 (C. Taylor ed.1985).

[FN63]. See MACINTYRE, supra note 59, at 220; SANDEL, supra note 61 , at 178-80; see also Cornell, Toward A Modern/Postmodern Reconstruction of Ethics, 133 U.PA.L.REV. 291, 372-75 (1985) (reconceptualizing rights as belonging to citizens as members of society, not as individuals).

[FN64]. See generally Note, A Communitarian Defense of Group Libel Laws, 101 HARV.L.REV. 682 (1988) [hereinafter Note, Communitarian Defense]; Fried, Liberalism, Community, and the Objectivity of Values (Book Review), 96 HARV.L.REV. 960 (1983) (reviewing M. SANDEL, LIBERALISM AND THE LIMITS OF JUSTICE (1982)); Sagoff, The Limits of Justice (Book Review), 92 YALE L.J. 1065 (1983) (same).

[FN65]. See generally J. HANDLER, THE CONDITIONS OF DISCRETION: AUTONOMY, COMMUNITY, BUREAUCRACY (1986) [hereinafter J. HANDLER, CONDITIONS OF DISCRETION]; Handler, Dependent People, The State, and the Modern/Postmodern Search for the Dialogic Community, 35 UCLA L.REV. 999 (1988) [hereinafter Handler, Dependent People]. Cf. R. BERNSTEIN, BEYOND OBJECTIVISM AND RELATIVISM: SCIENCE, HERMENEUTICS AND PRAXIS 162-63 (1983) (mutual understanding, a willingness to listen, and the pursuit of correctness in dialogue are all part of "a powerful regulative ideal that can orient our practical and political lives"').

[FN66]. See Handler, Dependent People, supra note 65, at 1080-82. These preconditions include power, an opportunity to speak, and trust. See also Simon, Legality, Bureaucracy, and Class in the Welfare System, 92 YALE L.J. 1198, 1240-45 (1983) (discussing inadequacies and pernicious effects of a hostile and overbureacractized AFDC system); Taylor, Atonism, in PHILOSOPHY AND THE HUMAN SCIENCES, supra note 62, at 206 (free members of Western societies are developed and identified by the civilizations in which they are raised); Note, Communitarian Defense, supra note 64, at 692 (community may not compromise of the "shared commitments that make freedom possible"'). 
[FN67]. See Delgado, Dunn, Brown, Lee, \& Hubbert, Fairness and Formality: Minimizing the Risk of Prejudice in Alternative Dispute Resolution, 1985 WIS.L.REV. 1359, 1387-97 [hereinafter Delgado, Fairness and Formality] (informality of alternative dispute resolution will result in the fostering of racial and ethnic prejudices). Dialog theorists glide over this difficulty, apparently believing high-quality dialog can compensate for inequality of power among participants. See $\mathrm{J}$. HANDLER, CONDITIONS OF DISCRETION, supra note 65, at 295-96 (arguing that parents of children in need of special education have difficulty in dealing with powerful school boards); Handler, Dependent People, supra note 65, at 1103 (arguing that concrete incentives are needed for dialogism to succeed).

[FN68]. See T. EAGLETON, LITERARY THEORY: AN INTRODUCTION 73 (1983) (on difficulty of maintaining equal dialog); Handler, Dependent People, supra note 65, at 1001, 1102-04, 1113 (same); Reischauer, Welfare Reform: Will Consensus Be Enough?, BROOKINGS REV., Mar. 1987 , at 3, 7-8 (discussing obstacles to welfare reform, including the difficulty of maintaining effective dialog between welfare administrators and recipients); see also J. GRUBER, CONTROLLING BUREAUCRACIES: DILEMMAS IN DEMOCRATIC GOVERNANCE 104-06 (1987) (reporting that results of empirical study demonstrate that bureaucrats tend to engage in dialog only with other bureaucrats, not with members of the public); J. HANDLER, CONDITIONS OF DISCRETION, supra note 65, at 12, 94-116 (participatory decisionmaking will work only when conflict is not divisive and bureaucracy is receptive to it); Delgado, ADR and the Dispossessed: Recent Books About the Deformalization Movement, 13 L. \& SOC. INQUIRY 145, 153 (1988) (commenting that "surveys and polls indicate that most Americans harbor some degree of prejudice toward members of groups other than their own"'); Delgado, Fairness and Formality, supra note 67, at 1394 (whites tend to avoid close social contacts with blacks and other minorities).

[FN69]. See supra note 18 and sources cited therein.

[FN70]. Will the course of action I propose fragment the nonwhite community, weakening its net political power? It may reduce the power of the small number of middle-class blacks and Hispanics who find moderate liberalism appealing and who gain status in left circles by purporting to speak for (and deliver the votes of) all blacks and browns, but it should empower all the rest. See supra notes 19-20 and accompanying text.

[FN71]. See Crenshaw, Race, Reform, and Retrenchment: Transformation and Legitimation in Antidiscrimination Law, 101 HARV.L.REV. 1331, 1362 n. 119, 1376 n. 174 (1988); Curry, supra note 3, at 60, 62; Forum: What's Wrong With the Democrats?, HARPER'S, Jan. 1990, at 45, 49 ("Our issues will not work unless the gays, the blacks . . . leave the nominee alone ... so he can chase swing voters."'); Oreskes, Aides to Jackson, supra note 3, at A1, col. 6; see also Delgado, When A Story Is Just A Story: Does Voice Really Matter, 76 VA.L.REV. 95, 98-103 (1990) (legal scholars of color ignored by the legal establishment, especially in the area of civil rights law). Democrats, like Republicans, have been wooing the wealthy-"money talks"'-at the expense of the rank-and-file voter.

[FN72]. See Hitchens, The Repackaging of Dan Quayle, HARPER'S, Apr. 1990, at 68 (Republicans beginning to realize "they miscued on civil rights in the Sixties and must not do so again"'); Conservative's War on Poverty: Ideologue Kemp Pushes Social Agenda at HUD, Wash. Post, Feb 25, 1990, at A1, col. 5 (discussing Secretary of Housing and Urban Development Kemp's "ambitious plan to fix a host of ailing entitlement and subsidy programs"').

[FN73]. See G. BECKER, THE ECONOMICS OF DISCRIMINATION 14 (2d ed.1971); M. FRIEDMAN, CAPITALISM AND FREEDOM 13 (2d ed.1982); P. WONNACOTT \& R. WONNACOTT, supra note 41 , at 437.

[FN74]. T. SOWELL, RACE AND ECONOMICS 161-72 (1975) (arguing that minorities have been 
denied access to the American job market through deprivation of "cultural capital"'). Many liberals urge the government to provide outgroups with job training and other forms of cultural capital. See, e.g., G. MYRDAL, AN AMERICAN DILEMMA 208 (2d ed.1962); T. PETTIGREW, EPITAPH FOR JIM CROW 46 (1964); THE SOCIOLOGY OF RACE REFLECTIONS: REFLECTIONS AND REFORMMMMMMMM (T. Pettigrew ed.1980) (collection of essays by liberal theorists tracing the history of black efforts to participate successfully in the U.S. economy); see also sources cited supra Part II.A Liberals generally make this argument for primarily altruistic or social engineering reasons, rather than the ones discussed here. This may, however, change if the U.S. economy declines further. See infra note 77.

It is worth noting that the right often think of "social welfare"' in different terms from the left. The right think of job training and police services; the left, of food stamps, medical care, etc.

[FN75]. See Handler, Transformation, supra note 64, at 484 (our aid programs for what we regard as undeserving poor are ungenerous and retributive).

[FN76]. That is, the poor have nothing legitimate to exchange. As a result, many turn to crime. See supra notes 10-11 (citing newspaper and statistical accounts of crimes committed by the poor); infra notes 78-79, 81 (citing sources that chronicle crimes committed by blacks). Could it be argued that society did provide social capital to the youth's parents, who squandered it? This argument seems unduly harsh, and goes too far. It would be a valid ground for denying aid to wastrel parents, but not to their blameless children.

[FN77]. It might be objected that the analytic argument to the right rests on a moral argument (that everyone deserves a chance to compete) that I rejected earlier in the argument to the left. See supra notes 45-58 and accompanying text. But the ability to enter markets is a logical precondition of markets' functioning. If one is committed, as conservatives are, to a marketplace economy, one must provide the relevant actors with the means of entry; no further moral step is required. See also infra note 83 (addressing possibility that a conservative might limit the market to persons like himself or herself).

Nothing about the conservative argument limits it to blacks and other nonwhite groups; poor whites need "cultural capital,"' too. Indeed, nothing prevents a coalition of poor whites and nonwhites from agitating to get the right to recognize their need for meaningful entry into national economic life.

[FN78]. See Kotlowitz, Urban Trauma: Day-to-Day Violence Takes a Terrible Toll on Inner-City Youth, Wall St. J., Oct. 27, 1987, § A, at 1, col. 1 (telling a similar story regarding a twelveyear-old Chicago youth); see also E. LIEBOW, TALLEY'S CORNER: A STUDY OF NEGRO STREETCORNER MEN (1967) (study of two dozen low-income black men living in a poor neighborhood); Delgado, "Rotten Social Background"': Should the Criminal Law Recognize a Defense of Severe Environmental Deprivation?, 3 L. \& INEQUALITY J. 9 (1985) (proposing that the law recognize "socioeconomic deprivation"' as a criminal defense for defendants who share characteristics similar to those of the youth described here).

[FN79]. See Handler, Transformation, supra note 4, at 466 (noting a growing perception that large segments of our population are trapped in an "'underclass"'). In a recent year, $43.1 \%$ of black children lived below the poverty line. STATISTICAL ABSTRACT, supra note 1, at 454 (table 738) (1987 figure); see also Gelman, Black and White in America, NEWSWEEK, Mar. 7, 1988, at 18, 20-23. (providing statistics on high poverty among blacks); Bernstein, 20 Years After the Kerner Report: Three Societies, All Separate, N.Y. Times, Feb. 29, 1988, at B8, col. 1 (citing statistics that point to low overall economic status of blacks, particularly black youths).

[FN80]. See H. THOREAU, Civil Disobedience, in SELECTED WORKS OF THOREAU 792 (H. Canby ed.1975) ("All men recognize the right of revolution; that is, the right to refuse allegiance to, and to resist, the government, when its tyranny or its inefficiency are great and unendurable."'); see also J. HABERMAS, LEGITIMATION CRISIS 33-94 (1975) (arguing that a 
social crisis can be avoided in advanced capitalistic societies only by a transformation of the existing class hierarchy).

[FN81]. See sources cited supra notes 6-11, 78-79; Booth, Fast Population Growth, Social Problems Linked, Wash. Post, June 26, 1989, at A2 (United States has "'moderate"' political stability due to population growth, ethnic divisions, and high youth unemployment accompanied by high expectations).

[FN82]. See Portrait of the Electorate, N.Y. Times, Nov. 10, 1988, at B6, col. 1 (N.Y. Times/CBS News Poll) (indicating that most high-income voters voted for Bush, while most low-income voters voted for Dukakis in the 1988 presidential election).

[FN83]. Cf. Gibbs, Wilding in the Night, TIME, May 8, 1989, at 20 (attack on wealthy Central Park victim triggered "fears of a troubled age"' across nation); Hacker, Black Crime, White Racism, N.Y. REV. BOOKS, Mar. 3, 1988, at 36 (blacks are "more likely to pick whites as their victims"' because "whites carry more cash or items of value"').

[FN84]. See Forum, supra note 73, at 53. A conservative may, of course, decide that it is cheaper to purchase more barbed wire, burglar alarms, and police dogs than it is to invite my ghetto youth to play Monopoly. This would not be a principled response, however, and it raises the risk of a miscalculation leading to the sort of disruption and violence discussed above.

Urging the right not to take this hunker-down turn may provide a role for the black and brown middle class. Although their interests will generally be aligned with the left, who favor affirmative action, environmentalism, and other causes of concern to middle class minorities, these blacks have an interest in opposing "Fortress America"' and can be expected to side with their brothers and sisters in the underclass in opposing police dragnets, buzzers in specialty stores, and other offensive security measures likely to affect nonwhites.

[FN85]. See generally 9 AM.JUR.2D Bankruptcy $\S 1$ (1980).

[FN86]. See id. at 44.

[FN87]. Id.

[FN88]. See A. COHEN \& M. MILLER, CONSUMER BANKRUPTCY MANUAL 1: 1-2 (1985).

[FN89]. Id.; see also Thurow, A Theory of Groups and Economic Redistribution, 9 PHIL. \& PUB.AFF. 25, 27-29 (1979) (describing economic life as a series of individual good and bad shocks, or "breaks,"' in which patterns of discrimination only appear in large groups).

[FN90]. See supra note 40. Compare the example of the hypothetical youth described therein and at supra text accompanying notes 78-81 with the well-known bailouts of Lockheed Corporation and New York City. The latter two rescue operations were undertaken even though Lockheed and New York contributed to their own predicaments through unwise business and spending policies. The hypothetical youth did not. Nor is his problem one of lack of effort; he simply has not been equipped to compete. Compare the works of Horatio Alger, 19th century clergyman who wrote inspirational books for boys. His message was that poor but honest, hardworking youth can rise in our freemarket system. Few of his heroes resemble our hypothetical ghetto youth, however. Most could read, had parents or benefactors, and were white.

[FN91]. See Harrison \& Gorham, Affirmative Action and Competitiveness, N.Y. Times, Apr. 22, 1990, at A13, col. 1; Wicker, Minorities Mustn't Be Neglected, Denver Post, Jan. 16, 1990, at 7B, col. 5 ("If we are to compete effectively in the world economy, we need minority and poor youngsters to produce, rather than become dependent on . . . or shoot at us."' (quoting Marian Wright Edelman)); Woo, Brokerage Invests in Students, Guarantees College Scholarships, L.A. Times, Nov. 22, 1988, $\S 1$, at 3, col. 4 (Merrill Lynch program guaranteeing scholarships for 250 
inner-city students nationwide); see also Handler, Transformation, supra note 4, at 501-02 (federal government requires that every state establish a Job Opportunities and Basic Skill Program (JOBS) with on-the-job training or educational activity); cf. id. at 491 (workfare programs popular with conservative groups); id. at 513 (supply of trained workers is greatly inadequate; some believe the future looks even worse).

[FN92]. See, e.g., Wineke, Church Gives 10 Kids Chance to Go to College, Wis. St. J., Sept. 28, 1989, at 1, col. 5; Teltsch, Business Sees Aid to Schools As a Net Gain, N.Y. Times, Dec. 4, 1988 , $\S 1$, at 1, col. 1; Fiske, Lessons, N.Y. Times, Aug. 10, 1988, at B6, col. 1 (wealthy industrialist offered to pay ghetto schoolchildren's college education if they stayed in school).

[FN93]. See supra notes 19, 57 and accompanying text.

[FN94]. See San Antonio Independent School District v. Rodriguez, 411 U.S. 1 (1973) (5-4 decision); Lindsey v. Normet, 405 U.S. 56 (1972) (5-vote majority decision); Dandridge v. Williams, 397 U.S. 471 (1970) (6-3 decision). I exclude from my discussion criminal dueprocess cases such as Griffin V. Illinois, 351 U.S. 12, 19-20 (1956) (due process requires that indigent defendants seeking appellate review of their convictions be provided with free copies of their final transcript).

[FN95]. 405 U.S. 56 (1972).

[FN96]. Id. at 73.

[FN97]. Id. at 74.

[FN98]. 411 U.S. 1 (1973).

[FN99]. Id. at 32-33 (quoting Lindsey, 405 U.S. at 74).

[FN100]. Id. at 29-30, 33-37.

[FN101]. Id. at 54-55. Nevertheless, a more recent decision implies that states may not charge tuition fees that exclude poor children entirely from receiving a public education. Plyler $\mathrm{V}$. Doe, 457 U.S, 202, 221-24 (1983). By focusing on the "pivotal role of education in sustaining our political and cultural heritage,"' the Court held that a state cannot deny the children of illegal aliens, referred to as members of a "permanent caste"' and "underclass,"' the free public education afforded to citizens and legal aliens. Id. at 218-19; see also Kadrmas v. Dickinson Pub. Schools, 487 U.S. 450, 469 (1989) (states may allow some local school boards, but not others, to charge parents for busing children to school, even if poor families cannot afford the fee).

[FN102]. 397 U.S. 471 (1970).

[FN103]. Id. at 472-75.

[FN104]. Id. at 484-86.

[FN105]. Id. at 508 (Marshall, J., dissenting); see generally Michelman, The Supreme Court, 1968 Term-Foreword: On Protecting the Poor Through the Fourteenth Amendment, 83 HARV.L.REV. 7 (1969).

[FN106]. See Karst, supra note 1, at 19 ("prevailing equal protection doctrine imposes no remedial obligation on government absent a showing of state 'action' that can be called invidious discrimination"' (footnote omitted)); see also Bork, Commentary: The Impossibility of Finding Welfare Rights in the Constitution, 1979 WASH.U.L.Q. 695, 695 (disagreeing "with the 
thesis that welfare rights derive in any sense from the Constitution or that the courts may legitimately place them there"'). For an impassioned defense of the idea that the Constitution implies a right to subsistence, see Black, Further Reflections on the Constitutional Justice of Livelihood, 86 COLUM.L.REV. 1103 (1986); see also Karst, supra note 1, at 3 ("We are ready to view the poor as people who deserve their poverty because they have chosen not to try."').

[FN107]. By politics I mean both electoral and informal politics, used even to the point of disruption. Will the nonwhite poor mobilize behind electoral political opportunities? Yes, if they can see that these are likely to benefit them. See Handler, Dependent People, supra note 65, at 1110 . On the need for threat and disruption to make any effort credible, see supra text accompanying notes $81-84$.

[FN108]. See generally Bumiller, Victims in the Shadow of the Law: A Critique of the Model of Legal Protection, 12 SIGNS 421 (1987). This is, of course, one of the stated concerns with providing welfare assistance.

[FN109]. See Delgado, Ever Saved?, supra note 1, at 923, 923-24 (1988).

[FN110]. See id. at 933-94. The chief exponent of this "interest convergence"' hypothesis is Derrick Bell. See generally Bell, Brown v. Board of Education and the Interest-Convergence Dilemma, 93 HARV.L.REV. 518 (1980) (positing that Brown was an inevitable result of a brief period of time when the interests of blacks and whites converged).

[FN111]. To be specific: the right should court and recruit minority poor and the nonwhite poor should appeal to principled conservatives for support for social welfare programs essential to equal opportunity and cultural capital, such as school reform, job training, and improved neighborhood services, including sanitation and police protection.

78 GEOLJ 1929

END OF DOCUMENT 